Volume 10, No.6, November - December 2021

International Journal of Advanced Trends in Computer Science and Engineering

Available Online at http://www.warse.org/IJATCSE/static/pdf/file/ijatcse141062021.pdf

https://doi.org/10.30534/ijatcse/2021/141062021

\title{
Review on The Effect of Alcohol Usage as A Fuel Additive in Internal Combustion Engine
}

\author{
Sarbani Daud ${ }^{1}$, Mohd Adnin Hamidi ${ }^{1,4}$, Rizalman Mamat ${ }^{2}$, Senthil Kumar ${ }^{3}$ \\ ${ }^{1}$ Faculty of Mechanical and Automotive Engineering Technology, Universiti Malaysia Pahang, 26600 Pekan, \\ Pahang, Malaysia \\ ${ }^{2}$ College of Engineering, Universiti Malaysia Pahang, 26300 Gambang, Pahang, Malaysia \\ ${ }^{3}$ Faculty of Industrial Management, Universiti Malaysia Pahang, 26300 Gambang, Pahang, Malaysia \\ ${ }^{4}$ Automotive Engineering Center, Universiti Malaysia Pahang, 26600 Pekan, Pahang, Malaysia
}

Received Date : October 10, 2021 Accepted Date : November 14, $2021 \quad$ Published Date : December 06, 2021

\begin{abstract}
The transportation sector holds a big share of the emission to the atmosphere. The emission of Green House Gas (GHG) leads to the thinning of the ozone layer. This situation leads to global warming. An international summit in Kyoto 1997 decided to stabilize the Green House Gas (GHG) emission. Therefore, many types of research have been conducted to reduce emissions. Improving engine performance is another method to reduce the amount of gasoline usage. One of the methods is to reduce emissions is by using alternative fuels. hydrogen, alcohol, and biofuel are among the examples. Among the alternatives, alcohol is a very popular alternative used in an internal combustion engine. This paper aims at reviewing the effect of alcohol on the performance and emission of the use of alcohol inside the spark-ignition engine. This review has confirmed that alcohol serves as good alternative fuel, especially if it is mixed at a good ratio with gasoline. With a good blend of alcohol-gasoline, emission can be reduced significantly.
\end{abstract}

Key words: Alcohol, engine emission, engine performance, gasoline, spark-ignition engine.

\section{INTRODUCTION}

The transportation sector holds a big share of the emission to the atmosphere [1-6]. The emission of Green House Gas (GHG) effects leads to the thinning of the ozone layer [7, 8]. This situation leads to global warming [9-13]. The international summit in Kyoto 1997 decided to stabilize the Green House Gas (GHG) emission [14-18]. Therefore, many types of research have been conducted to reduce emissions [19-21]. One of the methods is to reduce emission is by using alternative fuels and additives such as hydrogen, alcohol, biofuel, and carbon nanomaterials [22-27]. Spark ignition engine first developed in late 1800 by Klaus Otto. The internal combustion engine has become the foundation for vehicles, agriculture, military operation as well as electricity generation [28-32]. However, the rapid use of the engine raises the issue of depleting fossil fuel [33-36]. Also, the emission from the engine impacts the atmosphere, ecosphere, and hydrosphere [37-40]. Alcohol family such as methanol, ethanol, propanol is frequently used. Methanol $\left(\mathrm{CH}_{3} \mathrm{OH}\right)$ is preferable because of its availability and having good combustion behavior [41-45]. Another popular alcohol used is ethanol [46-50]. There is no modification required to the engine when using ethanol. By having high oxygen content, Ethanol increases the oxidation of harmful elements such as $\mathrm{CO}$ and HC. Propanol is the third member of the alcohol family [51, 52]. There are not many kinds of research that have been conducted on using it as an alternative fuel. The reason for this is the high production cost of propanol [53-55]. The other member of the alcohol family used as an alternative fuel is butanol [56-60]. There are four types of butanol namely $\mathrm{CH}_{3} \mathrm{CH}_{2} \mathrm{CH}_{2} \mathrm{CH}_{2} \mathrm{OH}$ (n-butanol), secondary butanol $\mathrm{CH}_{3} \mathrm{CH}_{2} \mathrm{CHOHCH}_{3}$ (2-butanol), isobutanol $\left(\mathrm{CH}_{3}\right) 2 \mathrm{CH}_{2} \mathrm{CHOH}$ (i-butanol), and t-butanol $\left(\mathrm{CH}_{3}\right) 3 \mathrm{COH}$ (t-butanol) [61]. All the butanol has the same formula and energy content[62, 63]. Quite many works of literature have been published on the mixture of gasoline-alcohol as an effort to reduce dependencies on fossil fuel. This review serves the purpose of investigating the latest development of alcohol usage in the spark-ignition engine.

\section{THE EFFECT OF GASOLINE-ALCOHOL MIXTURE TO THE ENGINE PERFORMANCE}

Edwin Geo [64] identifies in an experiment that Benzyl Alcohol blended in gasoline improves combustion,

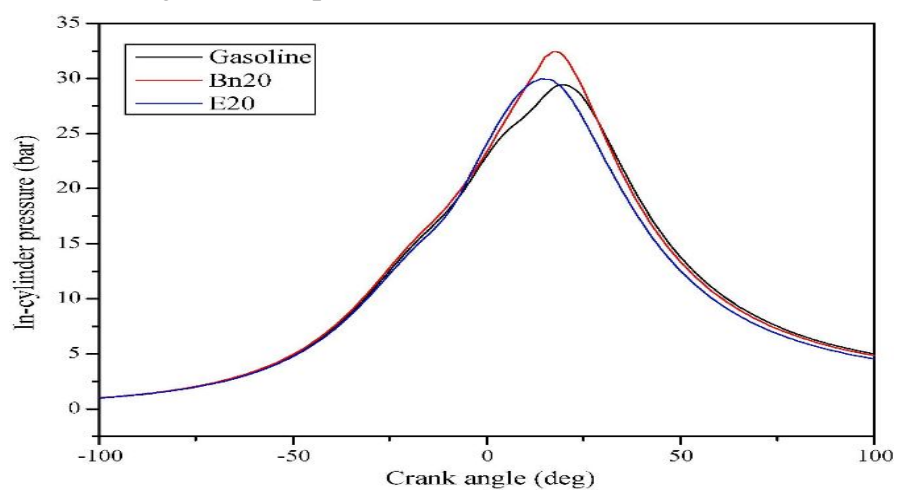

Figure 1. Comparison of in-cylinder pressure from different alcohol-gasoline blends [64] performance, and emission characteristics of the spark-ignition engine. The comparison of pressure produced from pure gasoline and gasoline-alcohol blend is illustrated in Figure 1. 
Sarbani Daud et al., International Journal of Advanced Trends in Computer Science and Engineering, 10(6), November - December 2021,3165 - 3172
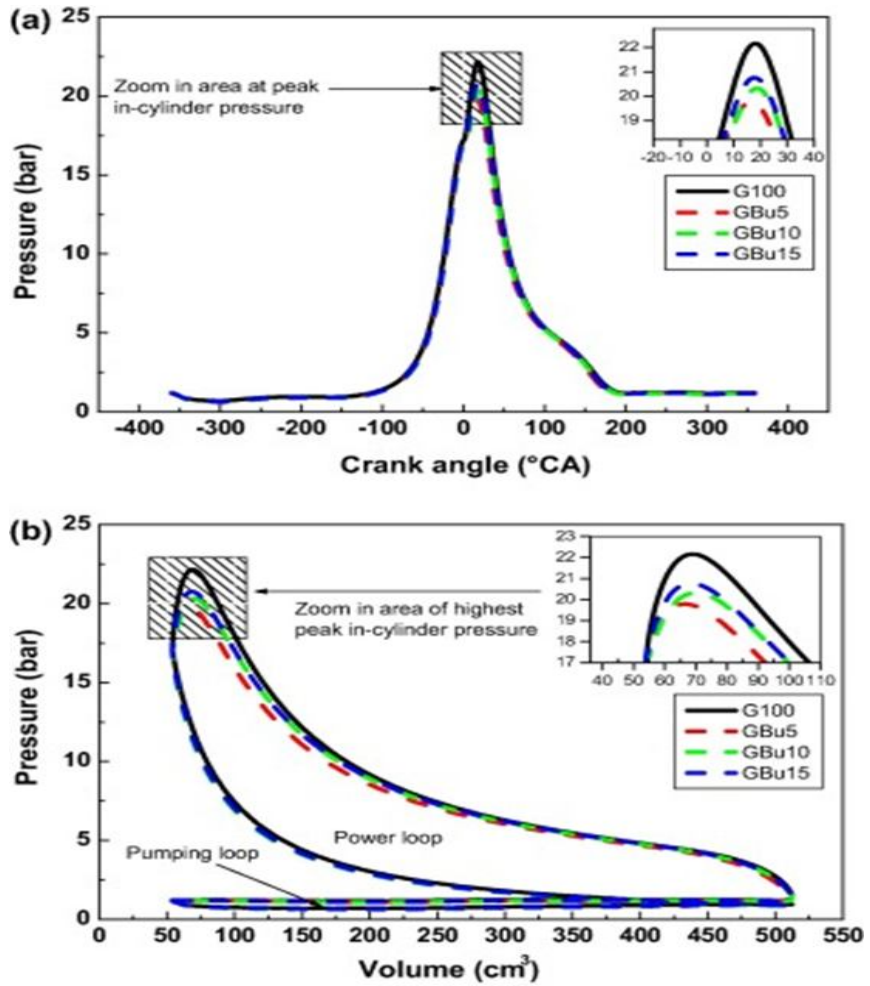

Figure 2. a) Pressure vs Crank Angle b) Pressure vs Volume [65]

In contrast, Balki[65] concluded that cylinder pressure from the Butanol-gasoline blend is lower than the engine running with pure gasoline. Figure 2 shows the different cylinder pressure produced by different blends.Using a single-cylinder gasoline engine, Mishra [66] demonstrated the effect of a gasoline-methanol mix on the performance and emission of a spark-ignition engine. It was noted that at lower rpm, the blend of alcohol-gasoline produced significantly higher power than pure gasoline. Figure 3 shows the difference between the power curves of the pure gasoline compared to the alcohol-gasoline blend at lower rpm.

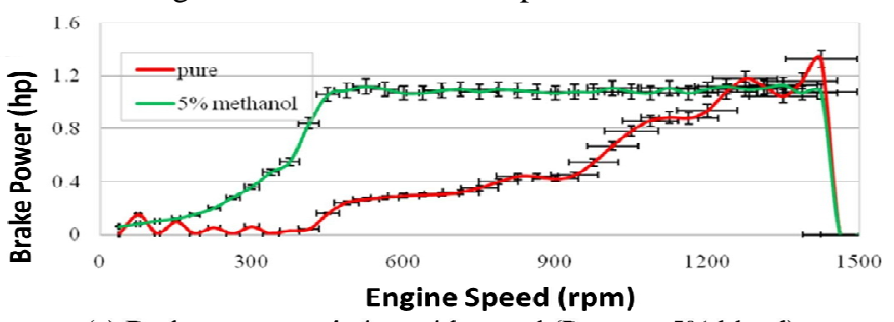

(a) Brake power variation with speed (Pure vs. $5 \%$ blend)

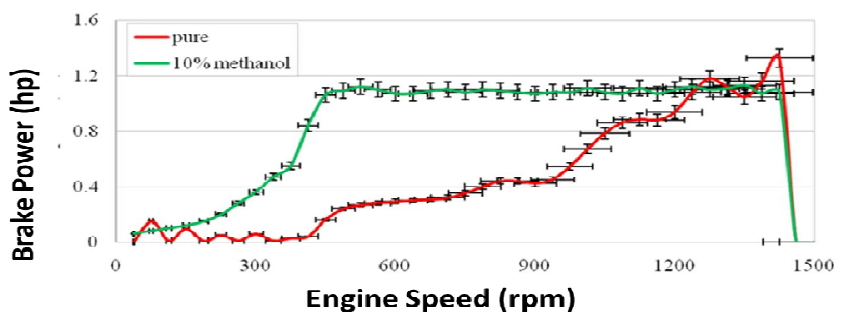

(b) Brake power variation with speed (Pure vs. $10 \%$ blend)

Figure 3. Power comparison between pure gasoline vs methanol-gasoline blend[66]
In another study by S. Phuangwongtrakul [67], a different mixing ratio of ethanol was investigated. Brake torque and brake specific fuel consumption (BSFC) were measured. The result from the experiment showed that proper ethanol-gasoline mixing ratio can improve engine torque. The result is shown in Figure 4.

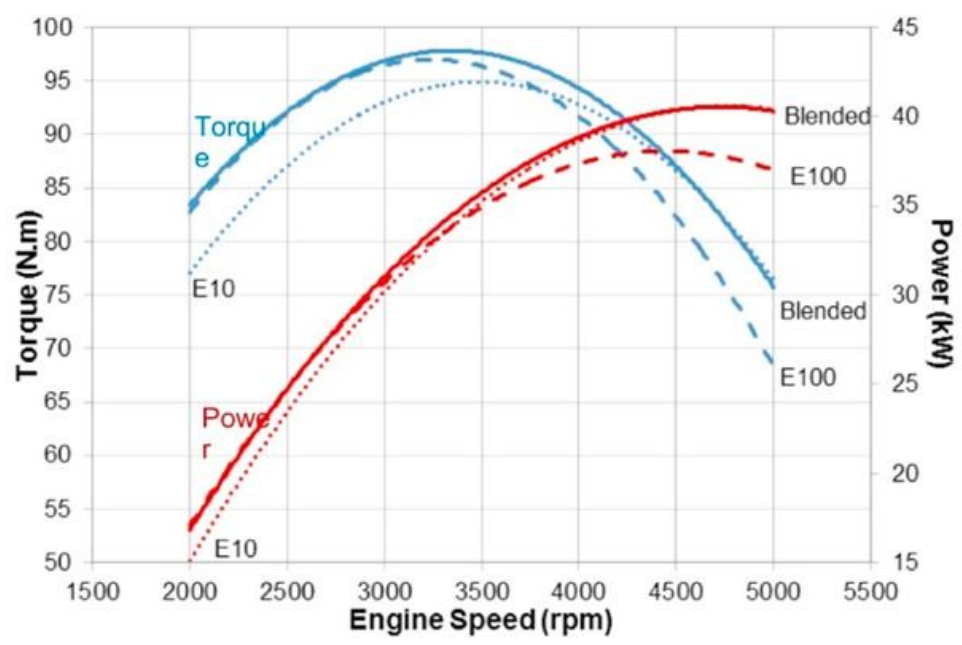

Figure 4. Torque and Power vs Engine Speed [67]

Yusri [68] experimented to find methods to improve energy management in Spark-ignition engines. Gasoline-butanol is used in the 4-cylinder Spark-ignition engine. It was found out that IMEP becomes higher with the addition of 2-Butanol. Besides, the emission produced by the engine also has been reduced. Sayin and Sarikaya[65] experimented using the DOE Taguchi method \& ANOVA. The objective was to find optimum parameters that will give the maximum engine performance and acceptable exhaust emissions. In this experiment, a 1-cylinder spark-ignition engine was used. Engine speed, compression ratio, and ignition timing were set as the variables. From the analysis it is found that the 9.0 was the optimum Compression Ratio, optimum engine speed value was $2400 \mathrm{rpm}$.

Najafi [69] experimented to estimate the performance and the exhaust emission of a four-cylinder spark-ignition engine. The engine operated on the different mixing ratios of ethanol-gasoline blends. A mixture of gasoline and bioethanol derived from potato peel $0 \%, 5 \%, 10 \%, 15 \%$, and 20 have been employed. The mixture was called E0, E5, E10, $\mathrm{E} 15$, and E20. The engine performance and emission from the mixture have been compared with the performance and emission from $100 \%$ gasoline. The result from the experiment shows that Engine Torque, brake Power (BP), Brake Thermal Efficiency (BTE), and Volumetric Efficiency improved by applying ethanol blends. However, in contrast, the brake specific fuel consumption (BSFC) decreased.

In addition, Mourad [70] showed that the use of ethanol/butanol blend in as additive in spark-ignition has improved the characteristics of the performance and emission of the engine. 
Sarbani Daud et al., International Journal of Advanced Trends in Computer Science and Engineering, 10(6), November - December 2021, 3165 - 3172

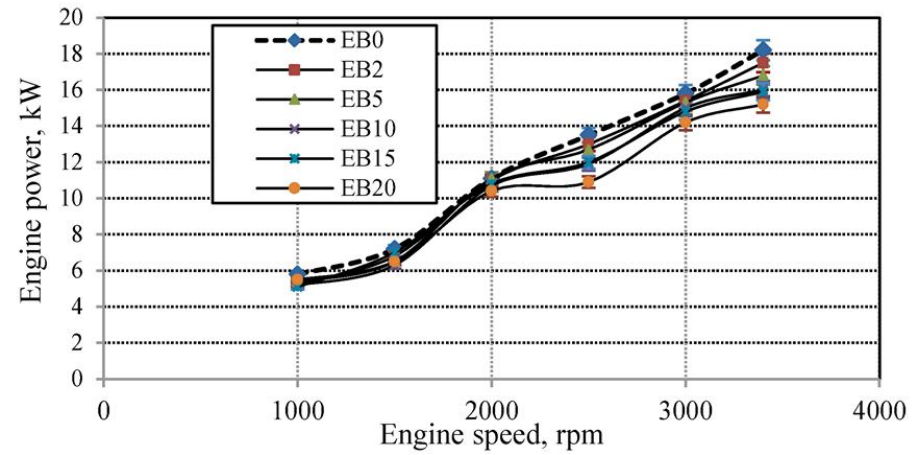

Figure 5. Engine power comparison between different ethanol-butanol blend [70]

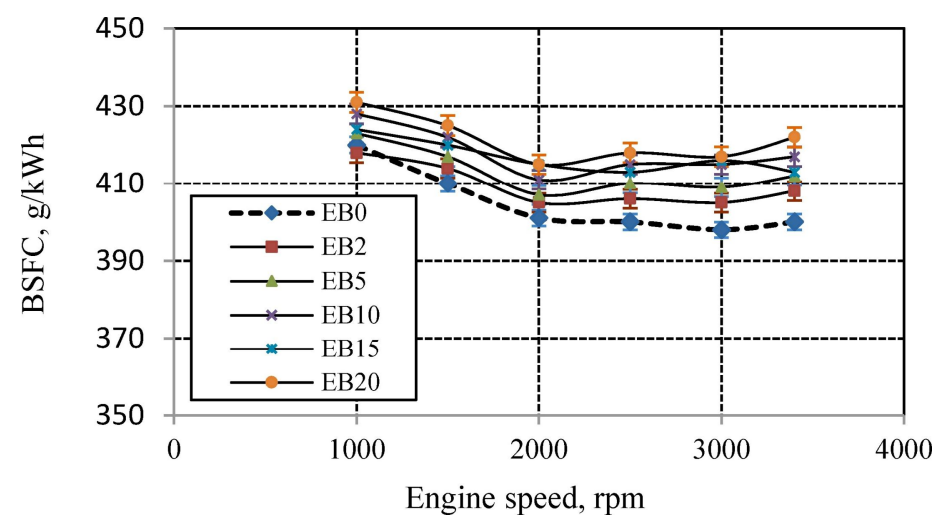

Figure 6. BSFC from different ethanol-butanol blends[70]

Figure 5 shows that the power produced from the blend is lower compared to power produced by $100 \%$ gasoline. The lower heating value of ethanol and butanol contributed to the result. In contrast, the BSFC of gasoline is about 5\% lower than the blends resulting from the higher heating value of gasoline. This behavior can be observed in Figure 6 .

In a different study, Efemwenkiekie [71] explored the different between spark ignition engine run with gasoline compared to gasoline-ethanol blend fuel. The ethanol was locally acquired in Nigeria. The finding shows that the blend of $3 \%$ ethanol and $97 \%$ gasoline give the best performance.

\section{THE EFFECT OF GASOLINE-ALCOHOL MIXTURE TO THE ENGINE EMISSIONS}

Mourad [70] performed an experiment to show the effects of alcohol on engine performance and engine emissions. Ethanol and Butanol were mixed with gasoline at $2 \%, 5 \%$, $10 \%, 15 \%$, and $20 \%$ of the mixture. The engine was run with different speeds at low load. Important findings suggest that the emissions significantly reduced when the engine run with the alcohol mixture. Figure 7 and Figure 8 show the lower emission of $\mathrm{HC}$ and $\mathrm{CO}$ from the alcohol-gasoline blend combustion.

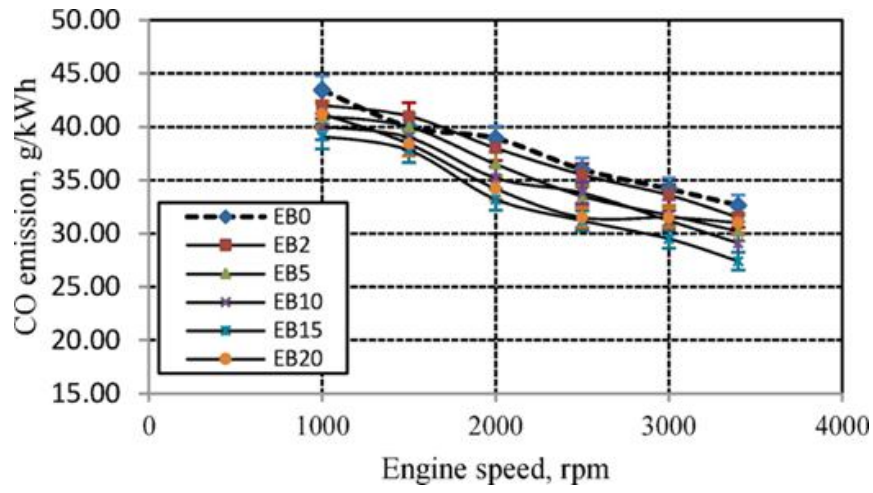

Figure 7. HC emission at different speeds [70]

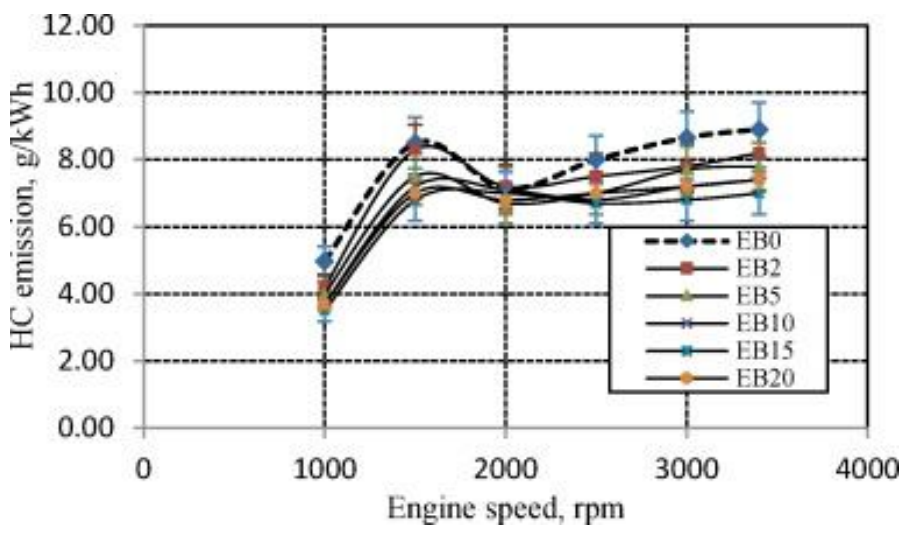

Figure 8. CO emission at different speeds [70]

From Najafi [69], the result from emission showed that the amount of $\mathrm{CO}$ and $\mathrm{HC}$ has been reduced, however $\mathrm{CO}_{2}$ and $\mathrm{NO}_{\mathrm{X}}$ emissions were higher.

According to a study by Amirabedi [72], Gasoline was mixed with $10 \%$ Ethanol. From the result, emission of NOx, HC, and $\mathrm{CO}$ all have been reduced. Only $\mathrm{CO}_{2}$ increased. This is mainly due to the higher rate of complete combustions, reduced $\mathrm{CO}$ but then the molecules formed $\mathrm{CO}_{2}$. This fact is good because $\mathrm{CO}_{2}$ is not poisonous like $\mathrm{CO}$.

Similarly, Edwin Geo [64]found that the $\mathrm{CO}$ and $\mathrm{HC}$ are less in alcohol blended fuel compared to the engine run with pure gasoline. The comparisons are illustrated in Figure 9 and Figure 10.

From the emission side of Mourad[70] study, the blends clearly reduced the harmful emissions such as $\mathrm{CO}$ and $\mathrm{HC}$. The results are shown in figure 11 and figure 12. The reason for this result is the lower boiling points of the ethanol and butanol compared to gasoline. This property leads to the complete burning of the ethanol and butanol thus decreasing the emissions.

In a different study, Mehmet Ilhak [73] examined the effect of replacing gasoline with ethanol and acetylene. It was run at partial loads (25\% and 50\%). The speed was maintained at 1500rpm. Among notable result was that the UHC and NOx emission was lower than gasoline. 


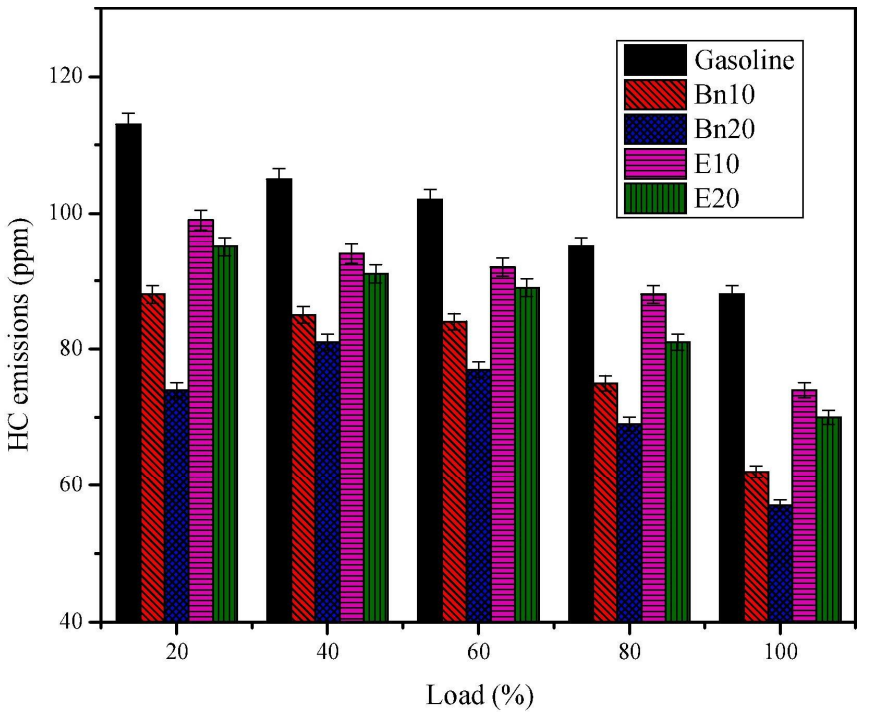

Figure 9. Comparison of HC emissions [64]

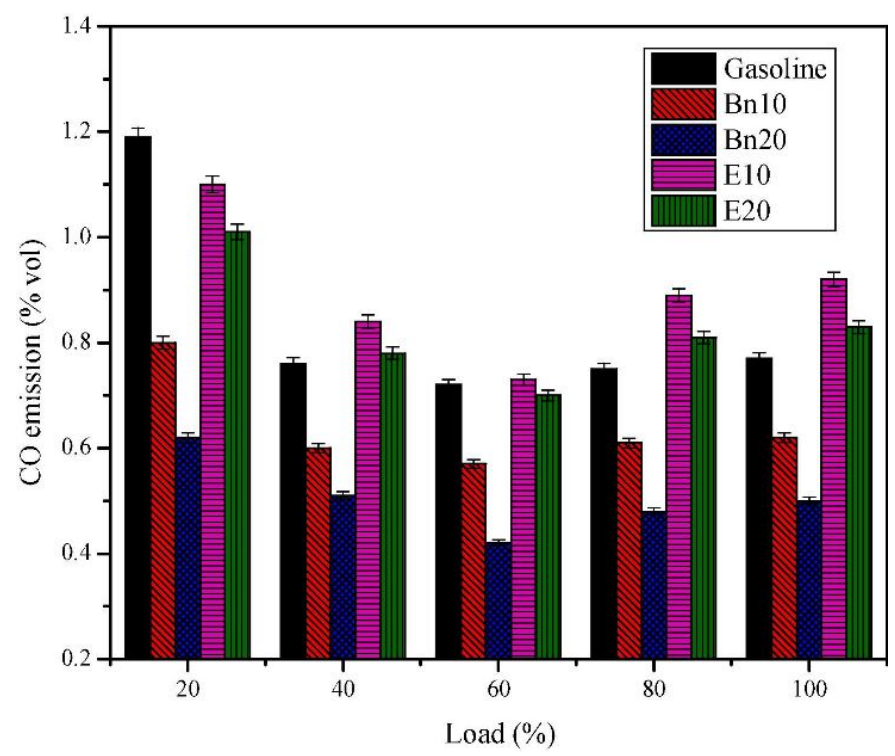

Figure 10. Comparison of $\mathrm{CO}$ emissions [64]

Another experiment conducted by Dogan in 2017 [74] to identify irreversible processes using energy and exergy analyses. The Fuels were blended at different ratios. 100\% unleaded gasoline is called E0, and gasoline blended with $10 \%$ ethanol is called E10. 20\% ethanol is called E20 and $30 \%$ ethanol is called E30. The fuel blends then applied into gasoline engines with different speeds, under different loads and under the same conditions for each fuel blends. The result from the experiments and theoretical calculations showed a reduction in carbon monoxide $(\mathrm{CO})$, carbon dioxide $(\mathrm{CO} 2)$, and nitrogen oxide (NOx) emissions without significant loss of power compared to the engine that runs fully on gasoline. However, the emission was increased. This was mainly due to the drop in the temperature inside the cylinder.

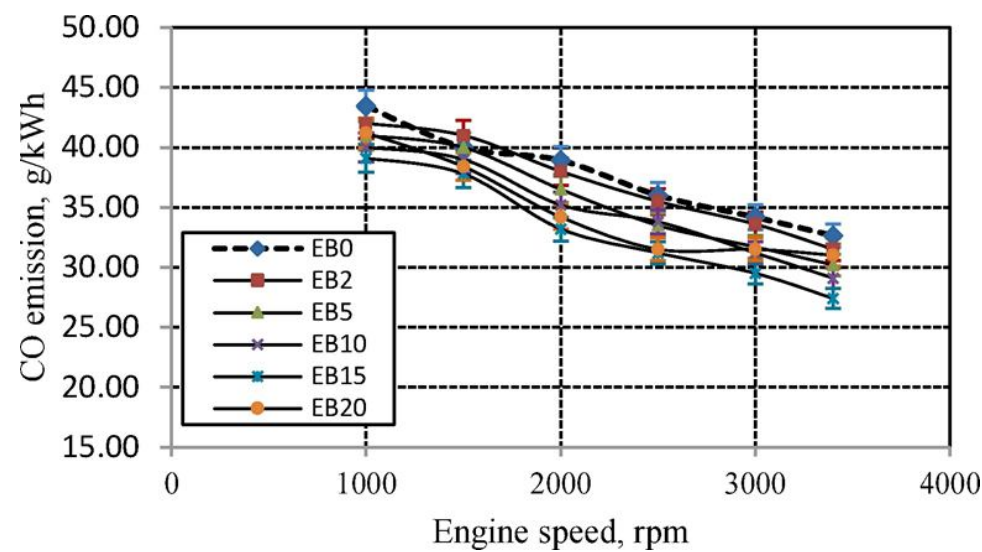

Figure 11. CO emissions from different ethanol-butanol blends[70]

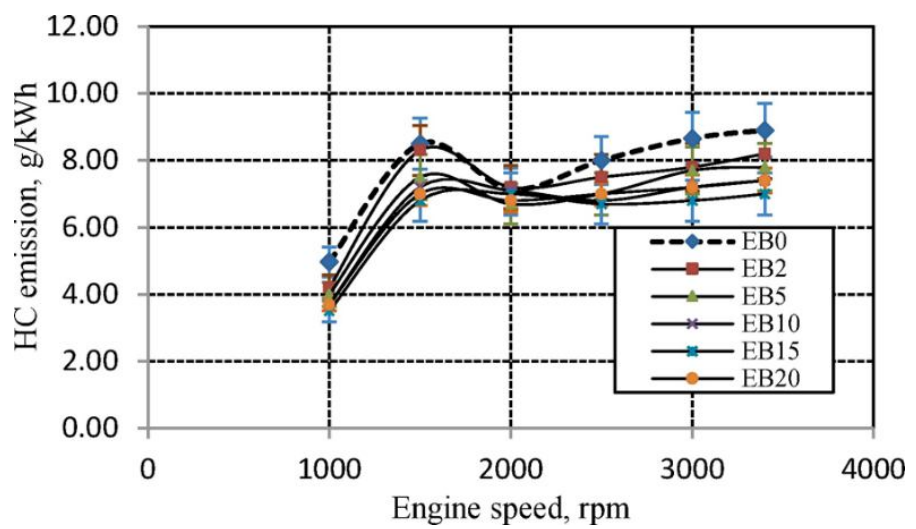

Figure 12. HC emissions from different ethanol-butanol blends [70]

To understand the concept further, Gravalos[75] experimented all popular alcohols (methanol, ethanol, propanol, butanol and pentanol) in a four-stroke spark ignition engine. The results are compared to the unleaded gasoline. It was observed that the $\mathrm{CO}$ emissions of alcohol blend is lower compared to neat gasoline. However, the result for $\mathrm{CO}_{2}$ was increased. The reason is because of higher oxygen content in alcohol make the higher quantity of unused oxygen during combustion.

\section{SUMMARY}

The readings can be summarized as below table:

Table 1: The results from different experiments

\begin{tabular}{|l|l|l|l|}
\hline Ref. & $\begin{array}{l}\text { Engine } \\
\text { Type }\end{array}$ & Fuel Blend & Result \\
\hline$[66]$ & $\begin{array}{l}\text { Single-c } \\
\text { ylinder } \\
\text { SI } \\
\text { Engine }\end{array}$ & $\begin{array}{l}\text { Methanol-gasoline } \\
5 \%, 10 \%, \text { and 15\% }\end{array}$ & Blend \% $\uparrow$, Power $\uparrow$ \\
\hline$[70]$ & $\begin{array}{l}\text { Four-cyl } \\
\text { inder } \\
\text { SI } \\
\text { Engine }\end{array}$ & $\begin{array}{l}\text { Ethanol \& butanol } \\
\text { mixed evenly with } \\
\text { gasoline. } \\
\text { Ratios 2\%, 5\%, 10\%, } \\
15 \% \text { and 20\% }\end{array}$ & $\begin{array}{l}\text { Blend \% } \uparrow, \text { Power } \downarrow \\
\text { Blend \% } \uparrow, \text { BSFC } \uparrow \\
\text { Blend \% } \%, \text { CO } \downarrow \\
\text { Blend \% } \%, \text { Nox } \downarrow\end{array}$ \\
\hline
\end{tabular}


Sarbani Daud et al., International Journal of Advanced Trends in Computer Science and Engineering, 10(6), November - December 2021, 3165 - 3172

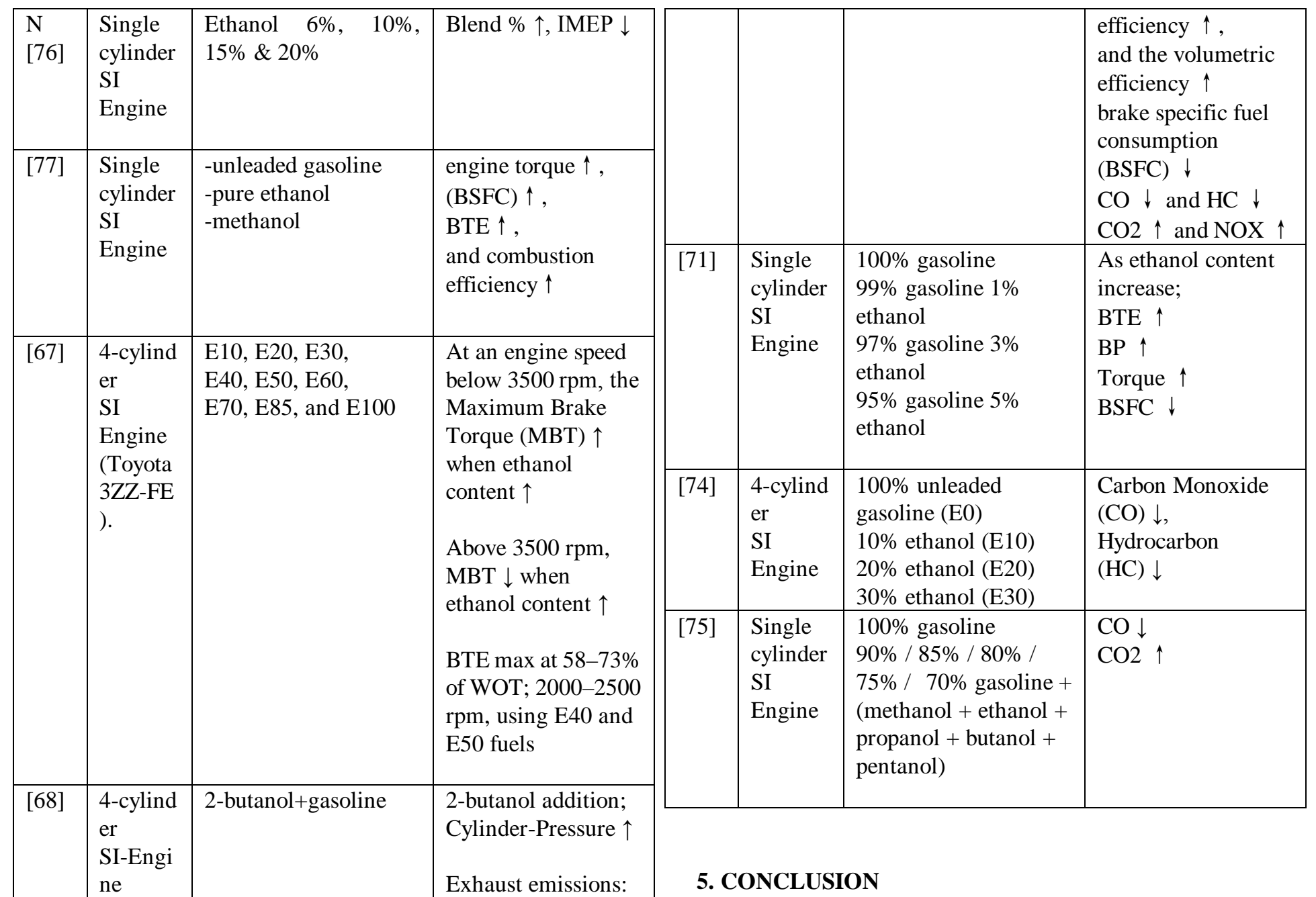

an average of lower

Nox. Gbu5 $\rightarrow$ less

$7.1 \%$, Gbu10 $\rightarrow$ less

$13.7 \%$,

and Gbu $15 \rightarrow$ less

$19.8 \%$.

optimum CR $\rightarrow 9.0$

optimum engine

speed $\rightarrow 2400$ rpm

for all fuels.

Optimum IT $\rightarrow 20$

crank angle (CA) for alcohol fuels, $26 \mathrm{CA}$ in gasoline

Results show that

the

Power \&

Torque $\downarrow$ when the ethanol $\% \uparrow$

After the

introduction of

ethanol blends

brake power $\uparrow$, the

engine torque $\uparrow$,

the brake thermal
These findings suggest that in general that the alcohol-gasoline mixture is a proven alternative fuel to reduce our heavy dependencies on fossil fuel. Many experiments have been conducted. For the performance, Power, Torque, and cylinder pressure were measured. For the emission, $\mathrm{CO}$, $\mathrm{CO}_{2}, \mathrm{NO}_{\mathrm{X}}$, and unburned $\mathrm{HC}$ were measured. In general, the engine performance is better when running with pure gasoline compared to when running with pure alcohol. On the other hand, the engine emission when running with alcohol-blend gasoline is better when compared to an engine run on pure gasoline.

\section{ACKNOWLEDGMENTS}

The financial support offered by Universiti Malaysia Pahang (www.ump.edu.my) under RDU190358 is gratefully acknowledged.

\section{REFERENCES}

1. Fan, Y.V., et al., A Review on Air Emissions Assessment: Transportation. Journal of Cleaner Production, 2018. 194: p. 673-684. 
Sarbani Daud et al., International Journal of Advanced Trends in Computer Science and Engineering, 10(6), November - December 2021 , 3165 - 3172

2. Kinnon, M.M., et al., Considering Future Regional Air Quality Impacts of the Transportation Sector. Energy Policy, 2019. 124: p. 63-80.

3. Kishimoto, P.N., et al., The Impact of Coordinated Policies on Air Pollution Emissions from Road Transportation in China. Transportation Research Part D: Transport and Environment, 2017. 54: p. 30-49.

4. Kumar, N.M., G.R. Reddy, and A. Miriyam, Potential Emission Reductions from India's Transport Sector: A View from the Green Transportation Projects under Cdm. Energy Procedia, 2018. 147: p. 438-444.

5. Liu, Y.-H., et al., Reduction Measures for Air Pollutants and Greenhouse Gas in the Transportation Sector: A Cost-Benefit Analysis. Journal of Cleaner Production, 2019. 207: p. 1023-1032.

6. Mark Van M. Buladaco, J.S.B., Laarni M. Cantero, Sentiments Analysis on Public Land Transport Infrastructure in Davao Region Using Machine Learning Algorithms. International Journal of Advanced Trends in Computer Science and Engineering, 2020. 9.

7. D.B. Hulwan, S.V.J., Multizone Model Study for Di Diesel Engine Running on Diesel-Ethanol-Biodiesel Blends of High Ethanol Fraction. International Journal of Automotive and Mechanical Engineering, 2018. 15(3).

8. Abas, C.H.L.a.M.A., One-Dimensional Simulation Using Port Water Injection for a Spark Ignition Engine. International Journal of Automotive and Mechanical Engineering. 15(4): p. 5803-5814.

9. Abeles, A.T., et al., Perception of Public Opinion on Global Warming and the Role of Opinion Deviance. Journal of Environmental Psychology, 2019.

10. Ding, Y., et al., Global Warming Weakening the Inherent Stability of Glaciers and Permafrost. Science Bulletin, 2019. 64(4): p. 245-253.

11. He, Q., et al., Climatic Suitability and Spatial Distribution for Summer Maize Cultivation in China at 1.5 and $2.0^{\circ} \mathrm{C}$ Global Warming. Science Bulletin, 2019.

12. Koutroulis, A.G., Dryland Changes under Different Levels of Global Warming. Science of The Total Environment, 2019. 655: p. 482-511.

13. Letcher, T.M., 1 - Why Do We Have Global Warming?, in Managing Global Warming, T.M. Letcher, Editor. 2019, Academic Press. p. 3-15.

14. Meinshausen, M., et al., Greenhouse-Gas Emission Targets for Limiting Global Warming to 2 C. Nature, 2009. 458(7242): p. 1158.

15. Peters, G.P. and E.G. Hertwich, Post-Kyoto Greenhouse Gas Inventories: Production Versus Consumption. Climatic Change, 2008. 86(1-2): p. 51-66.

16. Hoffert, M.I., et al., Advanced Technology Paths to Global Climate Stability: Energy for a Greenhouse Planet. science, 2002. 298(5595): p. 981-987.

17. Macedo, I.C., J.E. Seabra, and J.E. Silva, Green House Gases Emissions in the Production and Use of Ethanol from Sugarcane in Brazil: The 2005/2006 Averages and a Prediction for 2020. Biomass and bioenergy, 2008. 32(7): p. 582-595.

18. Satterthwaite, D., Cities' Contribution to Global Warming: Notes on the Allocation of Greenhouse Gas Emissions. Environment and urbanization, 2008. 20(2): p. 539-549.
19. M.N. Mohiddin, A.A.S., A.N.R. Reddy and S. Hamdan, A Study on Chicken Fat as an Alternative Feedstock: Biodiesel Production, Fuel Characterisation, and Diesel Engine Performance Analysis. International Journal of Automotive and Mechanical Engineering, 2018. 15(3).

20. Mishra, S.K.N.a.P.C., Analysis of a Diesel Engine Fuelled with Jojoba Blend and Coir Pith Producer Gas. International Journal of Automotive and Mechanical Engineering, 2017. 14(4).

21. B.P. Pattanaik, J.J.a.R.D.M., The Effect of Oxygen Content Is Soapnut Biodiesel-Diesel Blends on Performance of a Diesel Engine. International Journal of Automotive and Mechanical Engineering, 2017. 14(3).

22. Mofijur, M., et al., Investigation of Exhaust Emissions from a Stationary Diesel Engine Fuelled with Biodiesel. Energy Procedia, 2019. 160: p. 791-797.

23. Nag, S., et al., Experimental Study of Engine Performance and Emissions for Hydrogen Diesel Dual Fuel Engine with Exhaust Gas Recirculation. International Journal of Hydrogen Energy, 2019. 44(23): p. 12163-12175.

24. Najafi, B., et al., Modeling of a Dual Fueled Diesel Engine Operated by a Novel Fuel Containing Glycerol Triacetate Additive and Biodiesel Using Artificial Neural Network Tuned by Genetic Algorithm to Reduce Engine Emissions. Energy, 2019. 168: p. 1128-1137.

25. Ospina, G., et al., Engine Roughness and Exhaust Emissions of a Diesel Engine Fueled with Three Biofuels. Renewable Energy, 2019. 134: p. 1465-1472.

26. Zardini, A.A., et al., Reducing the Exhaust Emissions of Unregulated Pollutants from Small Gasoline Engines with Alkylate Fuel and Low-Ash Lube Oil. Environmental Research, 2019. 170: p. 203-214.

27. Vyacheslav Lyashenko, S.K.M., Svitlana Sotnik, M. Ayaz Ahmad, Basic Principles of Decision Making Upon Receipt of New Nanomaterial. International Journal of Advanced Trends in Computer Science and Engineering, 2019. 8.

28. Pawananont, K. and T. Leephakpreeda, Feasibility Analysis of Power Generation from Landfill Gas by Using Internal Combustion Engine, Organic Rankine Cycle and Stirling Engine of Pilot Experiments in Thailand. Energy Procedia, 2017. 138: p. 575-579.

29. Zhang, Z., et al., Research on the Engine Combustion Characteristics of a Free-Piston Diesel Engine Linear Generator. Energy Conversion and Management, 2018. 168: p. 629-638.

30. Hafiz, N.M., M.R.A. Mansor, and W.M.F. Wan Mahmood, Simulation of the Combustion Process for a $\mathrm{Ci}$ Hydrogen Engine in an Argon-Oxygen Atmosphere. International Journal of Hydrogen Energy, 2018. 43(24): p. 11286-11297.

31. Yadav, M., et al., Experimental Study on Emissions of Algal Biodiesel and Its Blends on a Diesel Engine. Journal of the Taiwan Institute of Chemical Engineers, 2019. 96: p. 160-168.

32. Yusri, I.M., et al., Evaluation of Engine Combustion and Exhaust Emissions Characteristics Using Diesel/Butanol Blended Fuel. Applied Thermal Engineering, 2019. 156: p. 209-219. 
Sarbani Daud et al., International Journal of Advanced Trends in Computer Science and Engineering, 10(6), November - December 2021, 3165 - 3172

33. Höök, M. and X. Tang, Depletion of Fossil Fuels and Anthropogenic Climate Change-a Review. Energy Policy, 2013. 52: p. 797-809.

34. Bauer, N., et al., Global Fossil Energy Markets and Climate Change Mitigation-an Analysis with Remind. Climatic Change, 2016. 136(1): p. 69-82.

35. Yinhui, W., et al., The Impact of Fuel Compositions on the Particulate Emissions of Direct Injection Gasoline Engine. Fuel, 2016. 166: p. 543-552.

36. Xing, J., et al., Individual Particles Emitted from Gasoline Engines: Impact of Engine Types, Engine Loads and Fuel Components. Journal of Cleaner Production, 2017. 149: p. 461-471.

37. Srinath Pai, A.S., and Shiva Kumar, Influence of Ultra Injection Pressure with Dynamic Injection Timing on Crdi Engine Performance Using Simarouba Biodiesel Blends. International Journal of Automotive and Mechanical Engineering, 2018. 15(4).

38. Mishra, S.K.N.a.P.C., Emission from a Dual Fuel Operated Diesel Engine Fuelled with Calophyllum Inophyllum Biodiesel and Producer Gas. International Journal of Automotive and Mechanical Engineering, 2017. 14(1).

39. Ismail, M.F.a.S., A Review on the Purification and the Use of Biogas in Compression Ignition Engine. 14, 2017. 3.

40. Zuhaira Abdullah, H.S., Adam Abdullah, Muhd Firdsaus Taufik, and Anes G. Mrwan, Effect of Pentanol-Diesel Fuel Blends on Thermi-Physical Properties, Combustion Characteristics, Engine Performance and Emissions of a Diesel Engine. International Journal of Automotive and Mechanical Engineering, 2018. 15(3).

41. Chen, Z., et al., Experimental Investigation on Performance and Combustion Characteristics of Spark-Ignition Dual-Fuel Engine Fueled with Methanol/Natural Gas. Applied Thermal Engineering, 2019. 150: p. 164-174.

42. Gong, C., et al., Influence of Ignition Timing on Combustion and Emissions of a Spark-Ignition Methanol Engine with Added Hydrogen under Lean-Burn Conditions. Fuel, 2019. 235: p. 227-238.

43. Li, Y., et al., Investigation on a High-Stratified Direct Injection Spark Ignition (Disi) Engine Fueled with Methanol under a High Compression Ratio. Applied Thermal Engineering, 2019. 148: p. 352-362.

44. Nidhi and K.A. Subramanian, Experimental Investigation on Effects of Oxygen Enriched Air on Performance, Combustion and Emission Characteristics of a Methanol Fuelled Spark Ignition Engine. Applied Thermal Engineering, 2019. 147: p. 501-508.

45. Wang, B., et al., Experimental Investigation on Methanol Auto-Ignition in a Compression Ignition Engine under Dmdf Mode. Fuel, 2019. 237: p. 133-141.

46. Awad, O.I., et al., Alcohol and Ether as Alternative Fuels in Spark Ignition Engine: A Review. Renewable and Sustainable Energy Reviews, 2018. 82: p. 2586-2605.

47. Awad, O.I., et al., Overview of the Oxygenated Fuels in Spark Ignition Engine: Environmental and Performance. Renewable and Sustainable Energy Reviews, 2018. 91: p. 394-408.

48. Elfasakhany, A., Investigations on Performance and Pollutant Emissions of Spark-Ignition Engines Fueled with N-Butanol-, Isobutanol-, Ethanol-, Methanol-, and Acetone-Gasoline Blends: A Comparative Study. Renewable and Sustainable Energy Reviews, 2017. 71: p. 404-413.

49. Thakur, A.K., et al., Progress in Performance Analysis of Ethanol-Gasoline Blends on Si Engine. Renewable and Sustainable Energy Reviews, 2017. 69: p. 324-340.

50. Yusri, I.M., et al., Alcohol Based Automotive Fuels from First Four Alcohol Family in Compression and Spark Ignition Engine: A Review on Engine Performance and Exhaust Emissions. Renewable and Sustainable Energy Reviews, 2017. 77: p. 169-181.

51. Han, G., et al., Mno 2 Nanorods Intercalating Graphene Oxide/Polyaniline Ternary Composites for Robust High-Performance Supercapacitors. Scientific reports, 2014. 4: p. 4824.

52. Jang, Y.-S., et al., Engineering of Microorganisms for the Production of Biofuels and Perspectives Based on Systems Metabolic Engineering Approaches. Biotechnology Advances, 2012. 30(5): p. 989-1000.

53. Choi, Y.J., et al., Metabolic Engineering of Escherichia Coli for the Production of 1-Propanol. Metabolic engineering, 2012. 14(5): p. 477-486.

54. Dusséaux, S., et al., Metabolic Engineering of Clostridium Acetobutylicum Atcc 824 for the High-Yield Production of a Biofuel Composed of an Isopropanol/Butanol/Ethanol Mixture. Metabolic Engineering, 2013. 18: p. 1-8.

55. Huo, Y.-X., et al., Conversion of Proteins into Biofuels by Engineering Nitrogen Flux. Nature Biotechnology, 2011. 29: p. 346.

56. Elfasakhany, A., Experimental Study of Dual N-Butanol and Iso-Butanol Additives on Spark-Ignition Engine Performance and Emissions. Fuel, 2016. 163: p. 166-174.

57. Fagundez, J.L.S., et al., An Investigation on Performance and Combustion Characteristics of Pure N-Butanol and a Blend of N-Butanol/Ethanol as Fuels in a Spark Ignition Engine. Energy, 2019. 176: p. 521-530.

58. Galloni, E., G. Fontana, and F. Scala, Experimental and Numerical Analyses of a Spark-Ignition Engine Firing with N-Butanol-Gasoline Blends at High Load Operation. Energy Procedia, 2018. 148: p. 336-343.

59. Li, Y., et al., Effect of Acetone-Butanol-Ethanol (Abe)-Gasoline Blends on Regulated and Unregulated Emissions in Spark-Ignition Engine. Energy, 2019. 168: p. 1157-1167.

60. Zaharin, M.S.M., et al., Evaluation on Physicochemical Properties of Iso-Butanol Additives in Ethanol-Gasoline Blend on Performance and Emission Characteristics of a Spark-Ignition Engine. Applied Thermal Engineering, 2018. 144: p. 960-971.

61. Chen, Z., et al., Metabolic Engineering of Klebsiella Pneumoniae for the De Novo Production of 2-Butanol as a Potential Biofuel. Bioresource Technology, 2015. 197: p. 260-265.

62. Jouzdani, S., A. Zhou, and B. Akih-Kumgeh, Propanol Isomers: Investigation of Ignition and Pyrolysis Time Scales. Combustion and Flame, 2017. 176: p. 229-244.

63. Frassoldati, A., et al., An Experimental and Kinetic Modeling Study of N-Propanol and Iso-Propanol Combustion. Combustion and Flame, 2010. 157(1): p. 2-16. 
Sarbani Daud et al., International Journal of Advanced Trends in Computer Science and Engineering, 10(6), November - December 2021, 3165 - 3172

64. Edwin Geo, V., et al., Effect of Higher and Lower

Order Alcohol Blending with Gasoline on Performance, Emission and Combustion Characteristics of Si Engine. Fuel, 2019. 256: p. 115806.

65. Balki, M.K., C. Sayin, and M. Sarıkaya, Optimization of the Operating Parameters Based on Taguchi Method in an Si Engine Used Pure Gasoline, Ethanol and Methanol. Fuel, 2016. 180: p. 630-637.

66. Mishra, P.C., et al., Methanol and Petrol Blended Alternate Fuel for Future Sustainable Engine: A Performance and Emission Analysis. Measurement, 2020. 155: p. 107519.

67. S. Phuangwongtrakul a, W.W.a., *, T. Sethaput b, K. Suktang a, S.Wongwises, Experimental Study on Sparking Ignition Engine Performance for Optimal Mixing Ratio of Ethanol-Gasoline Blended Fuels. Applied Thermal Engineering, 2016. 100 (2016) 869-879.

68. Yusri, I., et al., Experimental Investigation of Combustion, Emissions and Thermal Balance of Secondary Butyl Alcohol-Gasoline Blends in a Spark Ignition Engine. Energy Conversion and Management, 2016. 123: p. 1-14.

69. Najafi, G., et al., Svm and Anfis for Prediction of Performance and Exhaust Emissions of a Si Engine with Gasoline-Ethanol Blended Fuels. Applied Thermal Engineering, 2016. 95: p. 186-203.

70. Mourad, M. and K. Mahmoud, Investigation into Si Engine Performance Characteristics and Emissions Fuelled with Ethanol/Butanol-Gasoline Blends. Renewable Energy, 2019. 143: p. 762-771.

71. Efemwenkiekie, U.K., et al., Comparative Analysis of a Four Stroke Spark Ignition Engine Performance Using Local Ethanol and Gasoline Blends. Procedia Manufacturing, 2019. 35: p. 1079-1086.

72. Amirabedi, M., S. Jafarmadar, and S. Khalilarya, Experimental Investigation the Effect of Mn203 Nanoparticle on the Performance and Emission of $\mathrm{Si}$ Gasoline Fueled with Mixture of Ethanol and Gasoline. Applied Thermal Engineering, 2019. 149: p. 512-519.

73. İlhak, M.İ., et al., Experimental Study on an Si Engine Fueled by Gasoline, Ethanol and Acetylene at Partial Loads. Fuel, 2020. 261: p. 116148.

74. Doğan, B., et al., The Effect of Ethanol-Gasoline Blends on Performance and Exhaust Emissions of a Spark Ignition Engine through Exergy Analysis. Applied Thermal Engineering, 2017. 120: p. 433-443.

75. Gravalos, I., et al., Emissions Characteristics of Spark Ignition Engine Operating on Lower-Higher Molecular Mass Alcohol Blended Gasoline Fuels. Renewable Energy, 2013. 50: p. 27-32.

76. Schifter, I., et al., Combustion and Emissions Behavior for Ethanol-Gasoline Blends in a Single Cylinder Engine. Fuel, 2011. 90(12): p. 3586-3592.

77. Mustafa Kemal Balki a, C.S.b., $\Uparrow$, Mustafa Canakci, The Effect of Different Alcohol Fuels on the Performance, Emission and Combustion Characteristics of a Gasoline Engine. Fuel, 2012.

78. Gómez, A., et al., Modeling and Optimization of an Otto Cycle Using the Ethanol-Gasoline Blend. Revista Mexicana de Ingeniería Química, 2017. 16(3). 